knotting. But in the pregnant woman it is another matter ; one must use one's own judgment; the suture should be tied with very little tension. The two incisions are then closed with catgut in the ordinary way and the patient is sent back to bed. The foot of the bed should be raised for 48 hours or more if the patient is pregnant.

\section{Mode of Delivery}

With a history of repeated abortion and with a pregnancy which has reached term after this operative procedure it is tempting to deliver the child by means of caesarean section. Where there is no other obstetric indication, however, it seems reasonable to allow the patient to go into labour and divide the suture, which by this time may be found to lie just deep to the endocervical mucosa. Then, if labour proceeds normally within 48 hours, operative intervention is not indicated. If, however, after division of the suture delivery is not imminent after 48 hours, it seems to us desirable to deliver the patient by caesarean section.

\section{Discussion}

Without detailing the underlying causes, Malpas (1938) suggested that after three abortions the chance of spontaneous cure was $27 \%$. Swyer and Daley (1953), however, found that this pessimistic assessment was far too low ; that approximately $50 \%$ of such women had a chance of producing a live baby without treatment.

It is, of course, not difficult, in cases where there is a history of habitual abortion, to perform a Lash or Shirodkar type of operation, either before or during pregnancy, and if subsequently the patient carries to term there would be a natural tendency to claim that any successful result was due to the operation itself. In our opinion, success can be attributed to the operation only if a history of repeated early rupture of the membranes is obtained, or if actual incompetence of the internal os can be demonstrated.

It is quite obvious that to amass a series of cases sufficient to produce statistically significant results will take a long time owing to the relative rarity of this cause of habitual abortion. This preliminary communication is published in the hope that it may stimulate other workers in this field to carry out investigation and treatment along similar lines.

\section{Summary}

Deficiency of the internal cervical os is an occasional cause of habitual abortion. Such insufficiency may be either congenital or the result of trauma at gynaecological operation or during childbirth or miscarriage. The deficiency may be suspected from the history of repeated early rupture of the membranes followed by abortion, and may be demonstrated in the non-pregnant woman by a special $x$-ray technique or by the passage of a No. 4 cervical dilator freely into the uterine cavity. During pregnancy it may be confirmed by the observation that the membranes are bulging and that the cervix is partially dilated in the absence of bleeding or obvious uterine contractions.

A method of reinforcement of the inefficient internal os, based on Shirodkar's original technique, is described, and seven cases so treated are listed in detail. Five have now been delivered, and two are not yet pregnant.

ADDENDUM.- - Since submitting this paper for publication we have operated on five more patients between the 15 th and 20th weeks of pregnancy: none of these have aborted and all have proceeded to term normally.

REFERENCES

Aschoff, L. (1906). Z Geburtsh. Gynäk.. 58, 328.

Browne. F. J. (1950). Proc. roy. Soc. Med.. 43, 103.

Danforth, D. N. (1947). Amer. J. Obstet. Gynec., 53, 541.

Lash. A. F., and Lash, S. R. (1950). Ibid., 59, 68.

Malpas, P. (1938). J. Obstet. Gynaec. Brit. Emp., 45, 932

Rubovits. F. E., Cooperman, N. R., and Lash, A. F. (1953). Amer. J. Obstet. Gynec., 66. 269

Shirodkar. V. N. (1955). Tendences Actuelles en Gynécologie et Obstétrique p. 545 . Librairie de l'Université. Geneva. Swyer, G. I. M. and Daley, Doreen (1953). British Medical Journal, 1,
1073.

\section{PHARYNGO-CONJUNCTIVAL FEVER}

\section{SCHOOL OUTBREAKS IN ENGLAND DURING \\ THE SUMMER OF 1955 ASSOCIATED WITH ADENOVIRUS TYPES 3, 7, AND 14}

BY

\author{
E. J. C. KENDALL, M.B., M.R.C.P. \\ Epsom, Surrey
}

R. W. RIDDLE, M.B., D.P.H.

H. A. TUCK, M.B.

Shoreham-by-Sea, Sussex

K. S. RODAN, M.D.

Southlands Hospital, Shoreham-by-Sea, Sussex

B. E. ANDREWS, M.R.C.S., Dip.Bact.

AND

J. C. McDONALD, M.D., D.P.H.

Virus Reference and Epidemiological Research Laboratories, London

In 1954 Parrott and his colleagues reported a small outbreak of eight cases of febrile illness associated with type 3 adenovirus infection among patients and staff of a children's hospital in Washington. The main clinical features were pharyngitis, rhinitis, enlarged cervical lymph nodes, and conjunctival inflammation. Further outbreaks of an apparently identical illness occurring in the general population in the vicinity of Washington in the same year were described in detail by Bell et al. (1955). Once again type 3 adenovirus was apparently responsible, and the authors suggested that the disease be named pharyngo-conjunctival fever. Outbreaks of illness with clinical similarities occurred in Toronto in 1955 (Ormsby and Aitchison, 1955). Others had been described earlier by Guthrie and Pessel (1925) in a residential boys' school in New Jersey; by Derrick (1943) in association with a swimming-bath in Brisbane. Australia ; and by Cockburn (1953) in Greely, Colorado. Subsequent tests on paired sera from patients in the Greely epidemic showed rising titres of neutralizing antibody to type 3 adenovirus (Cockburn et al., 1956).

An epidemic of febrile pharyngitis and conjunctivitis associated with adenovirus type 4 infection occurred in Helsinki in the summer of 1955 (Forssell et al., 1956). In this epidemic, however, some differences in the symptomatology were observed; severe headache, gastrointestinal symptoms, and stiffness of the neck or back were found in many patients, and sinusitis was a common complication. Meningismus and other unusual signs were also noted by Sobel et al. (1956) in an outbreak of pharyngo-conjunctival fever in New Hampshire in 1955, in which there was evidence of type 3 infection. A school outbreak of acute respiratory illness associated with adenovirus type 7 infection occurred in the North of England in 1955 (Tyrrell et al., 1956). Conjunctivitis was seen in a small proportion of the cases.

During the summer of 1955 epidemics of an illness closely resembling that described by Bell et al. (1955) occurred in Lancing College and Epsom College, two residential boys' schools in southern England. This report is mainly concerned with an account of observations made in these schools. Later in the summer two of us (B. E. A. and J.C. McD.) assisted in the investigation of five other similar epidemics : four in residential 
boys' schools-Queen's College, Taunton; Wrekin College, Salop ; Wellingborough School, Northants ; and Roysse's School, Abingdon-and one in a Royal Naval training school for boys in Portsmouth. For permission to include information on these outbreaks we are indebted to Dr. C. G. M. Donaldson, Dr. J. Prentice, Dr. W. D. Arthur, and Dr. J. H. Fisher, the medical officers of the four schools, and to Surgeon Commander P. K. Fraser and the medical department of the Admiralty. In all, over 400 boys in the seven schools were sufficiently ill to require treatment in bed. Sickness rates in the individual schools ranged from 4 to $41 \%$. The duration and intensity of the epidemics varied greatly, as may be seen in Fig. 1, in which cases are shown by dates of onset. In three of the schools-Wrekin, Wellingborough, and Roysse's-more cases would probably have been recorded if the summer holiday had not intervened. Serological evidence of adenovirus infection was obtained from representative cases in all seven schools, and adenovirus strains were isolated from patients in five of them.

\section{Clinical Records}

Symptoms and signs and their severity were recorded for 116 patients at Lancing College and 53 patients at Epsom College who were considered on clinical grounds to be suffering from the epidemic disease, and who were admitted to the sanatorium. An effort was made to record the observations in as standard a manner as possible. At Epsom a further 8 boys who were treated for part of their illnesses at home are not included in the clinical analysis. In addition, 18 boys at Lancing and 8 boys at Epsom were admitted to the sanatorium with some other respiratory illness during the summer term; at Lancing six boys were admitted with rubella and one with glandular fever, and at Epsom one boy was admitted with glandular fever. The six cases of rubella were all in the same House, were clinically typical, and occurred in two groups, the first separated from the second by 16 to 21 days. The proportion of illnesses not classified as "pharyngo-conjunctival fever" was therefore small. In the other five schools a general description of the illnesses was obtained from discussion with the school doctors, and cases were seen and examined. As one of us (J.C.McD.) visited six of the seven outbreaks, some comparison of the clinical findings in each was possible.

\section{OUTBREAKS OF PHARYNGO-CONJUNCTIVAL FEVER}

\section{DATES OF ONSET OF ILLNESS IN BOYS ADMITTED TO SCHOOL SANATORIA OR KEPT HOME FROM SCHOOL}

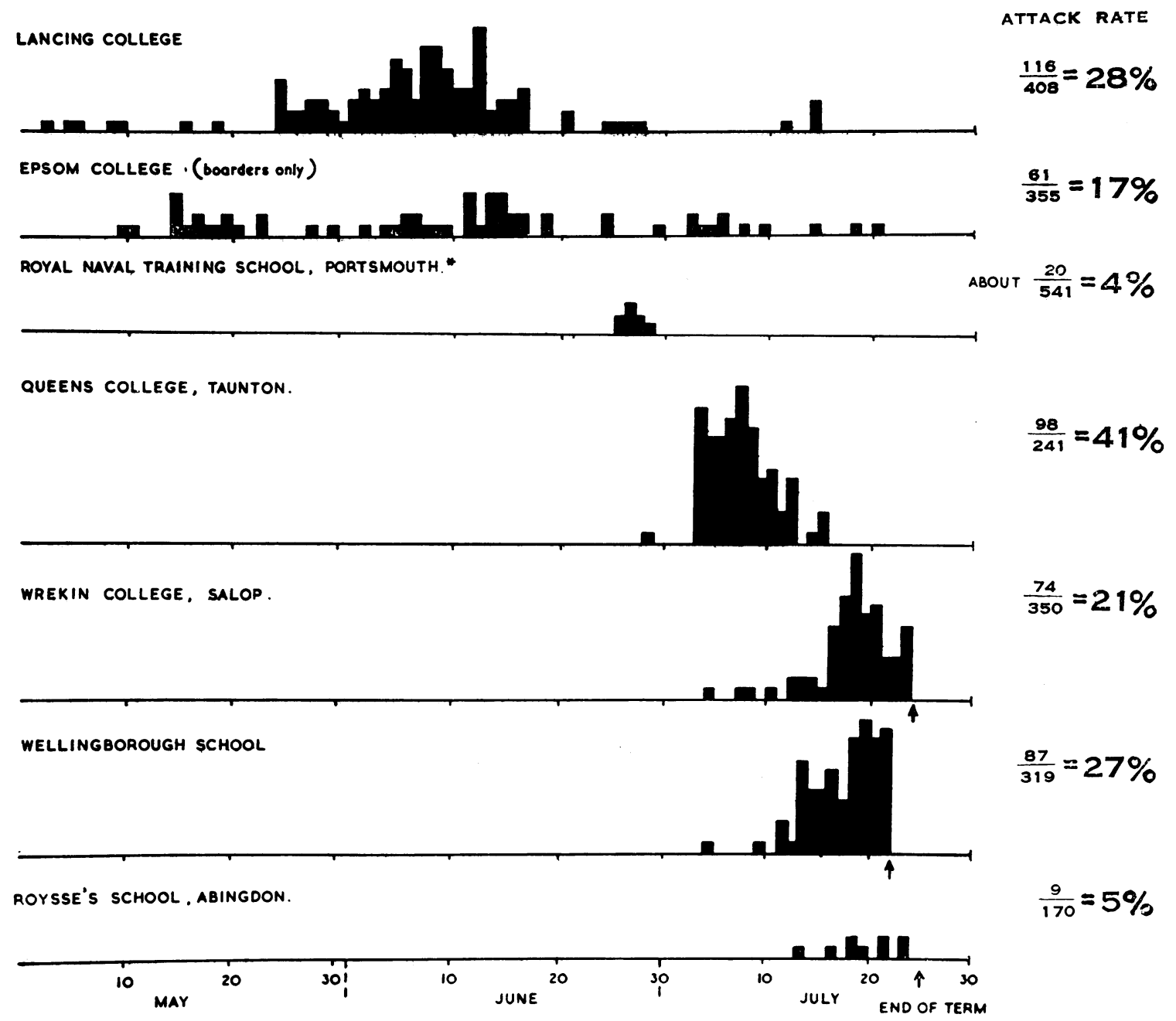

- one cAse

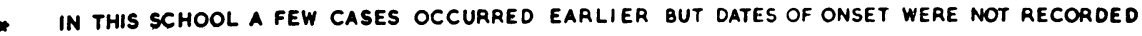

FIG. 1.-Outbreaks of pharyngo-conjunctival fever. Dates of onset of illness in boys admitted to school sanatoria or kept home from school. 


\section{Specimens}

Blood counts and bacteriological examinations of throat and eye swabs were made on a proportion of the Lancing and Epsom cases throughout the epidemic. Virological investigations were begun in early June. At Lancing College an attempt was then made to obtain blood specimens during the convalescent stage from as many as possible of those who had been ill, and paired acute and convalescent blood specimens from other boys who became ill subsequently. In addition, late convalescent specimens were taken from a small number of boys, most of whom had been bled at least once previously, on their return to school after the summer holiday. In all, one or more blood specimens were obtained from 71 of the 116 cases of pharyngo-conjunctival fever, from 7 of the 18 cases of other respiratory illness, and from all 7 cases with rubella or glandular fever. At Epsom College blood samples, single or paired, were obtained from a sample of the patients throughout the epidemic, 17 of the 53 patients being tested. In the remaining five schools paired sera were available from 30 typical cases. The number of pairs from individual schools ranged from 3 to 10 . Specimens of serum were stored at $-30^{\circ} \mathrm{C}$. until tested.

Specimens for virus isolation were obtained from the conjunctival sac or throat of a small number of acutely ill patients in five of the schools, but not in Queen's College, Taunton, or in the naval training school, where all cases were convalescent when visited. Conjunctival specimens were taken by means of a cotton-wool swab on a wooden stick. Immediately after collection the swab was transferred to a 5 -ml. screw-capped bottle containing 2 to $3 \mathrm{ml}$. of nutrient broth. The wooden stick was broken off and the cap screwed on tightly. Throat washings were taken in $10 \mathrm{ml}$. of saline, to which 2 to $3 \mathrm{ml}$. of nutrient broth was immediately added. Specimens were transported to the laboratory on solid carbon dioxide and subsequently stored in an electric refrigerator at $-70^{\circ} \mathrm{C}$.

\section{Laboratory Methods}

Sera were examined by the complement-fixation test performed in plastic plates of the type used for haemagglutination tests (World Health Organization, 1953). Serum, complement ( $2 \frac{1}{2}$ M.H.D.), and antigen were mixed in $0.1-\mathrm{ml}$. volumes and incubated at $37^{\circ} \mathrm{C}$. for 75 minutes, when 0.2 $\mathrm{ml}$. of a $1 \%$ suspension of sensitized sheep red cells was added. After 30 minutes at $37^{\circ} \mathrm{C}$. the plates were stored overnight at $4^{\circ} \mathrm{C}$. and the results read the next morning. Titres recorded as positive were the highest initial serum dilution showing approximately $75 \%$ of red cells unlysed. The antigen was used at the optimum dilution and was prepared from cultures of HeLa cells infected with R1-67 virus (adenovirus type 4). The medium and culture in bottles showing advanced degeneration were frozen at $-30^{\circ} \mathrm{C}$. overnight. After thawing, the contents were centrifuged, and the supernatant fluid was heated at $58^{\circ} \mathrm{C}$. for 30 minutes and then stored at $-30^{\circ} \mathrm{C}$. until required for use as antigen.

Virus isolation tests were performed by inoculation of $0.2 \mathrm{ml}$. of throat washings, or of the broth in which eye swabs had been stored, into each of two tubes of HeLa cell cultures. The cultures were left for at least 10 days and when necessary further passages were made. When characteristic degeneration occurred the cultures were frozen and thawed and the fluid was tested for the presence of adenovirus group antigen by complement-fixation with positive human convalescent serum. The HeLa cultures were grown in a medium containing $20 \%$ of human serum; before inoculation this was removed and the cultures were washed twice with a saline solution. The maintenance medium contained approximately $2 \%$ of chicken serum. Viruses were typed in HeLa tube cultures containing $1 \mathrm{ml}$. of medium to which was added $0.2 \mathrm{ml}$. of a virus-serum mixture prepared one hour previously and held at room temperature in the interval. Type-specific sera were prepared in rabbits which had received a series of intravenous injections of supernatant fluid from HeLa cultures infected with adenovirus prototype strains. The dose of the virus under test was adjusted to give complete degeneration in two to four days, and results were read 24 hours after the control tubes had shown complete degeneration. The specific sera used had titres between $1 / 300$ and 1/3,000 (original dilution in virus-serum mixture) to homologous virus, but did not neutralize heterologous viruses at a $1 / 30$ dilution. Viruses to be typed were screened against 1/30 dilutions of typespecific sera. Later, as a check, some of these strains were tested in parallel with viruses of known type against a full range of dilutions of the neutralizing serum.

\section{Clinical Features}

In all seven outbreaks the clinical features were very similar, though individual illnesses varied in severity and in the prominence of particular symptoms or signs. The illnesses were characterized by three to five days' fever, sore throat, blocked nose, enlarged cervical glands, painless conjunctivitis, and the absence of any involvement of the respiratory tract below the pharynx. Diarrhoea, vomiting, and abdominal pain were not generally complained of, but about a quarter of the patients at Epsom College and about a third at Queen's College, Taunton, had gastro-intestinal symptoms. These symptoms did not appear to be due to drug treatment. The frequency with which various symptoms and signs were recorded at Epsom and Lancing Colleges is shown in Table $I$. Percentage figures were usually lower at Lancing than at Epsom, particularly for the less prominent symptoms. We cannot be certain whether this was the result of differences in the illnesses or in the observers, but no essential difference was apparent to those of us who saw patients in both schools. For this reason it seemed permissible to give also in Table I an analysis of symptoms in a group of 29 cases, 20 from Lancing and 9 from Epsom, in whom a fourfold or greater rise in complement-fixing antibody was found in paired sera. The detailed clinical description that follows is based upon records of patients from both schools.

Prodromal symptoms of malaise and frontal headache were experienced by some patients, but in the majority the onset was sudden and accompanied by moderately sore throat, shivering, nausea, and mild aches in the legs or back. Occasionally nasal blockage, dizziness, faintness, vomiting, and diarrhoea were present at this stage and sometimes a

TABLE I.-Clinical Findings in Outbreaks of Pharyngoconjunctival Fever at Lancing and Epsom Colleges

\begin{tabular}{|c|c|c|c|c|c|}
\hline \multirow{3}{*}{\multicolumn{3}{|c|}{ Clinical Findings }} & \multicolumn{3}{|c|}{ Percentage of Boys in whom Observed } \\
\hline & & & \multicolumn{2}{|c|}{ Clinical Cases } & \multirow{2}{*}{$\begin{array}{c}\text { Serologically } \\
\text { Positive } \\
\text { Cases* } \\
\text { Epsom and } \\
\text { Lancing } \\
\text { (29 Cases) }\end{array}$} \\
\hline & & & $\begin{array}{c}\text { Lancing } \\
\text { (116 Cases) }\end{array}$ & $\begin{array}{l}\text { Epsom } \\
\text { ( } 53 \text { Cases) }\end{array}$ & \\
\hline 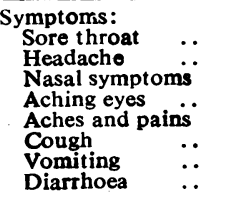 & 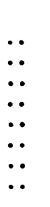 & \begin{tabular}{l|}
$\cdots$ \\
$\cdots$ \\
$\cdots$ \\
$\cdots$ \\
$\cdots$
\end{tabular} & $\begin{array}{l}72 \\
68 \\
41 \\
29 \\
25 \\
16 \\
3 \\
1\end{array}$ & $\begin{array}{l}85 \\
79 \\
75 \\
53 \\
41 \\
32 \\
25 \\
9\end{array}$ & $\begin{array}{l}79 \\
72 \\
66 \\
45 \\
38 \\
14 \\
7 \\
3\end{array}$ \\
\hline \multirow{2}{*}{\multicolumn{3}{|c|}{$\begin{array}{l}\text { Fever: } \\
\text { Present } \\
\text { Reaching } 102^{\circ} \dot{\mathrm{F}} .\left(38.9^{\circ} \mathrm{C} \text {. }\right) \text { and } \\
\text { lasting } 4 \text { days or more } \\
\text { Mean maximum in febrile cases }\end{array}$}} & 88 & 100 & 93 \\
\hline & & & $\begin{array}{l}53 \\
102.4^{\circ} \mathrm{F} . \\
\left(39 \cdot 1^{\circ} \mathrm{C}\right)\end{array}$ & $\begin{array}{l}55 \\
102 \cdot 2^{\circ} \mathrm{F} \\
\left(39^{\circ} \mathrm{C} .\right)\end{array}$ & $\begin{array}{l}55 \\
102 \cdot 5^{\circ} \mathrm{F} . \\
\left(39 \cdot 15^{\circ} \mathrm{C} .\right)\end{array}$ \\
\hline \multicolumn{3}{|c|}{ Mean duration in febrile cases } & 4.7 days & $4 \cdot 7$ days & 4.9 days \\
\hline $\begin{array}{l}\text { Conjunctivitis: } \\
\text { Present ... } \\
\text { Moderately severe } \\
\text { Severe .. . . } \\
\text { Eyes unequally affecte }\end{array}$ & $\ddot{c}$ & $\ddot{\cdots}$ & $\begin{array}{r}63 \\
31 \\
9 \\
28\end{array}$ & $\begin{array}{l}85 \\
34 \\
11 \\
19\end{array}$ & $\begin{array}{r}100 \\
48 \\
21 \\
62\end{array}$ \\
\hline \multicolumn{3}{|c|}{$\begin{array}{l}\text { Cervical lymph nodes: } \\
\quad \text { Enlarged } \quad . . \\
\text { Moderate or severe enlägement }\end{array}$} & $\begin{array}{l}77 \\
24\end{array}$ & $\begin{array}{l}89 \\
30\end{array}$ & $\begin{array}{l}97 \\
52\end{array}$ \\
\hline $\begin{array}{l}\text { Pharyngitis: } \\
\text { Present } \ldots \text { or severe } \\
\text { Moderate or }\end{array}$ & $\ddot{*}$ & $\ddot{*}$ & $\begin{array}{l}74 \\
45\end{array}$ & $\begin{array}{l}98 \\
51\end{array}$ & $\begin{array}{l}79 \\
41\end{array}$ \\
\hline
\end{tabular}

* Fourfold or greater rise in complement-fixing antibody in paired sera. 
little itching or aching in or behind the eyes. On examination the temperature was 101 to $102^{\circ} \mathrm{F}$. $\left(38.3\right.$ to $38.9^{\circ} \mathrm{C}$.), with a pulse rate of 80 to 110 . The patient appeared moderately ill, with a flushed face and an erythematous haze over the bulbar conjunctivae. The soft palate and anterior fauces were erythematous, and a few enlarged vessels or petechiae were sometimes seen in these areas. The lymphatic tissue of the posterior pharyngeal wall was red and hypertrophied. A scanty follicular exudate was seen on the tonsils or in the pharynx in about one-quarter of the patients. Purulent exudate was uncommon, and ulceration was not observed. A few translucent vesicles less than $1 \mathrm{~mm}$. in diameter were observed on the soft palate and faucial pillars in some cases; they were transient and were noi associated with erythema or ulceration. Small discrete glands up to about $1.5 \mathrm{~cm}$. in diameter were usually palpable in the posterior and anterior cervical groups, less often in the axillae, and occasionally in the inguinal regions. They were not tender. Preauricular adenopathy was not observed. The glandular enlargement was symmetrical and did not appear to be related to local inflammation. In nine cases-one at Lancing and eight at Epsom-the spleen was palpable, its size ranging from a palpable tip to three fingerbreadths of enlargement. It was smooth and not tender.

During the next two or three days the patients remained moderately ill and slightly drowsy, the temperature being sustained or remittent, with a maximum of 102 to $104^{\circ} \mathrm{F}$. $\left(38.9\right.$ to $40^{\circ} \mathrm{C}$.). The throat continued inflamed, the nose became blocked, and a posterior nasal discharge often developed, though the anterior nares remained dry and normal in appearance. Hoarseness and cough were never prominent symptoms and sputum was scanty. Abnormal signs in the chest were very uncommon and consisted of scattered rhonchi only. The conjunctival inflammation frequently increased at this stage. It was accompanied by very little discomfort. The lower palpebral conjunctivae became red and oedematous and moderate-sized vessels appeared over the bulbar conjunctivae. With more severe inflammation, the lower conjunctival sacs became oedematous and granular, and follicles were formed. A false membrane was seen in cne case. The discharge was usually watery: the eyelids rarely became sticky or matted. In the most severely inflamed eyes the palpebral and bulbar conjunctivae were intensely red. At any particular time one eye often appeared worse than the other, but by the end of the illness both eyes had usually been affected to some degree. In a few cases the conjunctivitis preceded or followed the main illness by three days or more. By the third or fourth day of illness the patients felt much better, the temperature falling by lysis over 24 to 48 hours, and the pulse rate returning to normal.

During the convalescent phase abnormal signs gradually resolved. A moderate degree of lassitude and shakiness was experienced, but within 14 days from onset most patients felt well and could undertake a full day's activity. By this time eyes, throat, glands, and upper respiratory tract had all become almost or quite normal. Relapses were not encountered and complications were uncommon. Two cases of moderately severe otitis media were observed; both resolved rapidly without otorrhoea. Routine chest $x$-ray films were not taken during the acute phase of the illness, but tasal shadows were found in two cases examined about three weeks after onset. A mass $x$-ray survey carried out at Lancing in early July revealed no further abnormalities that could be attributed to the infection. Albuminuria, jaundice, skin rashes, hepatic enlargement or tenderness, and abnormalities of the central nervous system were absent.

The clinical features described above are those of the fully developed case, which constituted about a third of the total. In about a fifth of the patients whose illnesses were otherwise similar the conjunctivae were unaffected. The remaining cases were less severe, and in about a quarter of them moderate or severe eye involvement occurred alone with little or no fever or constitutional disturbance. In all these clinical varieties serological evidence of infection was found.

Slit-lamp Examination.-Mr. A. J. Cameron kindly examined seven of the Epsom cases during the convalescent stage (11th to 18th day of illness). All these cases had had moderate or severe involvement of the eyes during the acute stage of the illness, but at the time of examination few abnormalities were apparent to the naked eye. In five of these cases, many groups of small lesions, staining with $1 \%$ rose Bengal, were seen at the limbus on the nasal conjunctival side. In one case small diffuse nebulae which did not stain were found over the cornea. The staining lesions were similar to those found in superficial punctate keratitis. In the remaining case no lesions were seen.

Treatment.-Either penicillin $(500,000$ or 250,000 units by intramuscular injection twice daily), chlortetracycline (250 $\mathrm{mg}$. four times a day), or sulphadimidine $1 \mathrm{~g}$. four times a day was given in representative cases, early in the illness. No effect on the patient's general condition was apparent. The course of the signs and of the fever appeared to be unaffected when compared with cases in which symptomatic treatment was given alone.

\section{Laboratory Findings}

Paired specimens of serum were available from 91 boys in the seven outbreaks investigated, and a fourfold or greater rise in complement-fixation titres was found in 52 cases (57\%). Material for the isolation of viruses had been taken from 42 patients in five of the schools and adenovirus strains were isolated from $25(60 \%)$ of them. The samples consisted of 33 throat washings from which 22 strains were isolated and 17 eye swabs which yielded 5 strains. These results are shown for each school in Table II. It will be

TABLE II.-Results of Serological and Virus Isolation Tests*

\begin{tabular}{|c|c|c|c|c|c|}
\hline \multirow{2}{*}{\multicolumn{2}{|c|}{ School }} & \multirow{2}{*}{$\begin{array}{l}\text { C.F. } \\
\text { Tests on } \\
\text { Paired } \\
\text { Sera }\end{array}$} & \multicolumn{3}{|c|}{ Virus Isolation Tests } \\
\hline & & & Patients & $\begin{array}{c}\text { Eye } \\
\text { Swabs }\end{array}$ & $\begin{array}{l}\text { Throat } \\
\text { Swabs }\end{array}$ \\
\hline $\begin{array}{l}\text { Lancing College } \\
\text { Epsom College } \\
\text { Wellingborough Colilege } \\
\text { Wrekin College } \\
\text { Roysse's School } \\
\text { Queen's College, Taunton } \\
\text { Nava! School } \quad . .\end{array}$ & $\begin{array}{l}\because \\
\therefore \\
\cdots \\
\cdots \\
\cdots\end{array}$ & $\begin{array}{l}20 / 50 \\
9 / 11 \\
2 / 3 \\
7 / 10 \\
6 / 6 \\
3 / 4 \\
5 / 7\end{array}$ & $\begin{array}{l}7 / 20 \\
6 / 8 \\
4 / 4 \\
5 / 6 \\
3 / 4 \\
= \\
-\end{array}$ & $\begin{array}{l}3 / 12 \\
\frac{1}{1 / 2} \\
\overline{1 / 3} \\
=\end{array}$ & $\begin{array}{l}5 / 14 \\
6 / 7 \\
4 / 4 \\
5 / 6 \\
2 / 2 \\
= \\
-\end{array}$ \\
\hline Total & . & 52,91 & $25 / 42$ & $5 / 17$ & $22 / 33$ \\
\hline
\end{tabular}

seen that serological evidence of infection was obtained in a number of boys at each school, and that where material had been taken for culture a number of strains were isolated from eye or throat swabs. There was satisfactory agreement between virus isolation and serological tests in the 35 cases where both types of specimen were available. A comparison of the two tests is shown in Table III.

TABLE III.-Comparison of Virus Isolation and Serological Tests in 35 Cases

\begin{tabular}{|c|c|c|c|c|}
\hline & & $\begin{array}{l}\text { C.F. } \\
\text { Test Positive }\end{array}$ & $\begin{array}{c}\text { C.F. } \\
\text { Test Negative }\end{array}$ & Total \\
\hline $\begin{array}{l}\text { Virus isolated } \\
" \text { not isolated }\end{array}$ & . & $\begin{array}{r}22 \\
6\end{array}$ & $\begin{array}{l}1 \\
6\end{array}$ & $\begin{array}{l}23 \\
12\end{array}$ \\
\hline Total .. & & 28 & 7 & 35 \\
\hline
\end{tabular}

At Lancing College only 20 out of 50 cases tested showed a rising titre of antibody-a lower proportion than in other schools. In 21 of the 50 the first serum specimen had been taken between 8 and 23 days from the onset of illness and only one of these showed a rise in titre in the second specimen. Most of these sera, however, showed a level of antibody consistent with the stage of illness. In the remaining 29 cases the first specimen of serum had been taken before the eighth day from onset of illness and $19(66 \%)$ showed a rise in titre. This proportion is similar to that 
obtained in the other schools, where almost all first specimens of serum had been taken within a week of onset of illness. At Lancing College serum was obtained three to four months after the illness from 47 boys who had shown an antibody titre of $1 / 8$ or more in an early convalescent specimen taken 10 to 30 days from onset of illness. The antibody titre had not altered more than twofold in $64 \%$;

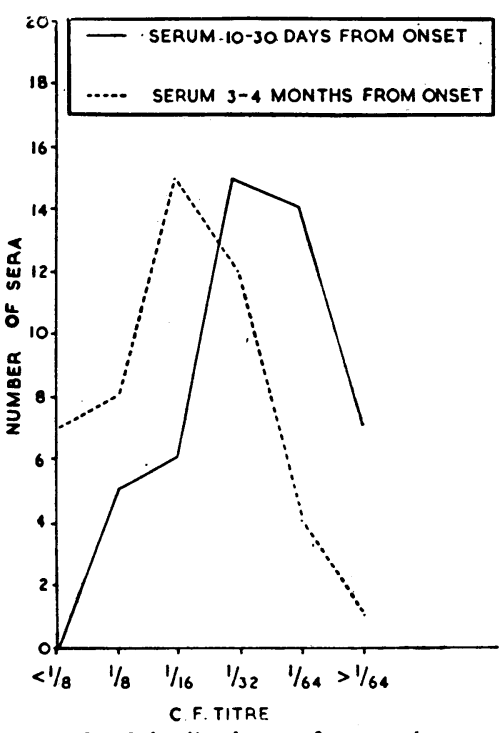

FIG. 2.-Distribution of complementfixation titres in 47 cases tested 10 to 30 days and three to four months from onset of illness. more than one serum, a nd a ll strains from on e school were of the cases examined with the exception of one case of typical glandular fever in each school. Complement-fixation tests for influenza were negative in each of the 24 cases tested.

\section{Epidemiological Observations}

All seven outbreaks occurred during the early months of the exceptionally warm dry summer of 1955 . Sports and other fixture lists were examined. but no connexion was discovered between the schools. Directors of public health and other laboratories throughout England and Wales and many school medical officers were informed in June that we were anxious to learn of any similar occurrences, but, apart from an outbreak in a school in the North of England during the autumn (Tyrrell et al., 1956) and one or two sporadic cases, we know of no other evidence of pharyngoconjunctival fever in Britain during 1955. In 1956 the laboratory assisted in the investigation of what was probably the same syndrome in a residential girls' school and found evidence of adenovirus type 7 infection in a sample of patients tested. A few scattered sporadic cases were again found in 1956.

It seemed improbable that if an illness with so striking a clinical picture had occurred in this country in epidemic form prior to 1955 it would not have been recorded. Accordingly we looked for any evidence of immunity in older age groups that might have resulted from past infection with the same virus. In Lancing, Epsom, and Wrekin Colleges illness attack rates were calculated by year of birth; these are shown in Table IV. It may be seen that

TABLE IV.-Illness Attack Rate by Year of Birth in Three Schools s a m e type. The results were as follows: Lancing College, 2 strains negative to types 1 to 8 inclusive; Epsom College, 6 strains type 7 ; Wrekin College, 3 strains type 3 ; Wellingborough College, 4 strains type 3 ; Roysse's School, 3 strains type 3.

Two strains from Lancing College were subsequently tested against serum specific for an adenovirus strain isolated from a case of respiratory illness in a Dutch military recruit. Thi $i_{i}$ serum neutralized the Lancing strain to the dilution obtained against the homologous virus. Professor van der Veen, who isolated the Dutch strain (deWit), has informed us that Dr. W. P. Rowe has classified it as the adenovirus type 14 prototype strain.* It was found that the Lancing virus strains took longer to cause degeneration of the HeLa cultures on primary isolation than did strains from the other schools. They were also found to lose titre on storage at $-30^{\circ} \mathrm{C}$. considerably more rapidly than is the case with other adenovirus types of which we have experience. These points may explain the relatively low isolation rates shown for Lancing College recorded in Table II.

At Lancing and Epsom Colleges throat and eye swabs from a proportion of cases were examined bacteriologically, total and differential white blood cell counts were made, and serum was tested for heterophil antibody and a rising titre of complement-fixing antibody to influenza viruses $\mathrm{A}, \mathrm{B}$, and $\mathrm{C}$. Bacteriological results generally showed a normal flora even in those cases where the throat appeared most inflamed, but in a few the growth consisted predominantly of haemolytic streptococci, pneumococci, Staphylococcus aureus, or Haemophilus influenzae. At Lancing College white-cell counts were normal or slightly low with a relative lymphocytosis; in most cases a few atypical mononuclear cells resembling those of glandular fever were present. These never exceeded $7 \%$ of the differential count. Such cells have been described in infectious hepatitis (Barker et al., 1945) and other virus infections, and in some allergic conditions (Randolph and Gibson, 1944). In a few cases there was an increase in eosinophils of up to $10 \%$. Similar results were found at Epsom College. The Paul-Bunnell test was negative in all

${ }^{*}$ A virus strain from the Lancing College outbreak has since been examined by Dr. W. P. Rowe, who confirms that it belongs to type 14 .

\begin{tabular}{l|c|c|c|c|c|c|c}
\hline \multirow{2}{*}{ School } & \multicolumn{6}{|c}{ Attack Rate (\%) for Those Born in: } \\
\cline { 2 - 8 } & 1936 & 1937 & 1938 & 1939 & 1940 & 1941 & $1942-3$ \\
\hline $\begin{array}{l}\text { Lancing College } \\
\text { Esom }\end{array}$ & 14 & 16 & 22 & 27 & 38 & 38 & 50 \\
Wrekin & 0 & 7 & 10 & 6 & 36 & 30 & 43 \\
\hline & 12 & 8 & 17 & 19 & 23 & 30 & - \\
\hline
\end{tabular}

attack rates fell with rising age in all three schools. Further evidence of immunity associated with age was the almost complete absence of illness among adult members of the staff in any of the schools. In the four outbreaks not shown in Table IV either the number of cases was too small or insufficient information was collected for age-specific attack rates to be calculated. However, it should be mentioned that there appeared to be little difference between the attack rates in senior and junior schoolboys at either Wellingborough School or Queen's College, Taunton.

The sequence of cases was studied in detail at Epsom and Lancing, but no pattern of spread of infection was apparent. However, boys in residential schools have so many different contacts with one another that the pattern of spread of infection by personal contact might well be obscured. Attack rates in houses, dormitories, and classes showed no difference greater than could be accounted for by age or chance. The onset of the outbreak at Queen's College, Taunton (see Fig. 1), had the explosive character often associated with food-borne infection, but this possibility was not investigated. It is interesting that it was in this school that gastro-intestinal symptoms were most prominent.

Swimming-baths have in some reports been suspected of spreading pharyngo-conjunctival fever. The seven outbreaks mentioned here took place during a hot summer, and all the schools had either a swimming-bath of their own or the use of one, so bathing may have played a part in spreading infection. At Lancing College, however, where the swimming-bath was closed on May 28, the subsequent course of the epidemic was not apparently affected.

No conclusive evidence was found on the length of the incubation period. Bell and his colleagues (1955), after study of the intervals between the onset of the first and subsequent cases in households, concluded that the incubation period was probably five to seven days. The distribution of intervals between first and later cases in dormitories at 
Lancing College and Epsom College, shown in Fig. 3, resembles that presented by Bell et al. and supports their conclusion.

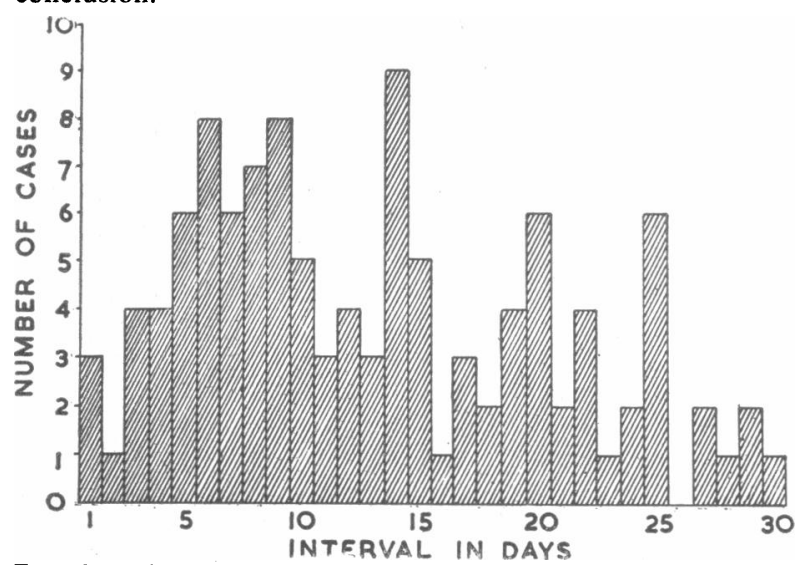

Fig. 3.-Distribution of intervals from onset of first case in dormitory to onset of subsequent cases (15 intervals of more than 30 days are not shown).

\section{Discussion}

Strong evidence has been given by Bell et al. (1955) that the syndrome called by them pharyngo-conjunctival fever was due to adenovirus infection. The clinical features of the seven school outbreaks reported here closely resembled this American description. In the five schools where virus isolation was attempted adenovirus strains were isolated and the presence of virus was found to be followed by an increase in complement-fixing antibody in 22 out of 23 cases tested. At Lancing College results were available which indicated that a rise in antibody titre could be shown only in cases from which the first specimen of serum had been taken within a week of onset of illness. It therefore seems probable that adenovirus infection was also the cause of the outbreaks in this country.

The differentiation of individual cases of pharyngo-conjunctival fever from other acute respiratory infections, in particular influenza, streptococcal sore throat, and glandular fever, might well be difficult without laboratory evidence. In epidemic form, however, the characteristics of the syndrome seem quite unlike those of any other. The rarity of cough, tracheitis, and bronchitis should distinguish pharyngo-conjunctival fever from influenza; the nasal symptoms, general non-tender enlargement of cervical glands, and relative absence of follicular or exudative pharyngitis should distinguish it from streptococcal infection. The character, severity, and frequency of the conjunctivitis is unlike that seen in these infections. The short non-relapsing course of the illness and the occurrence of an outbreak would make glandular fever an improbable diagnosis.

Too little is yet known of the full range of clinical manifestations of adenovirus infection to be sure that pharyngo-conjunctival fever could easily be distinguished from them all. It seems quite different from the febrile catarrh seen in military recruits in whom conjunctivitis is usually absent but in whom cough and bronchitis are usually present and pneumonic complications are not uncommon. Epidemic kerato-conjunctivitis, which may be dus to adenovirus infection and which is seldom accompanied by nasopharyngeal or febrile symptoms, is far more painful and the corneal damage is often much greater and lasts longer. Difficulties are more likely to arise if it should prove that the adenoviruses can cause other similar but not identical syndromes such as febrile pharyngitis unaccompanied by prominent conjunctivitis (Ginsberg et al., 1955) and outbreaks such as that in Helsinki (Forssell et al., 1956), where in addition to pharyngitis and conjunctivitis there were meningeal symptoms.

Type 3 adenovirus was isolated from the cases described by Bell and his colleagues. The same group of workers subsequently reported similar illnesses following conjunctival inoculation with viruses of types $1,3,4$, and 5 (Bell et al., 1956). Types 1,4 , and 5 have not, however, been reported in natural infections causing pharyngo-conjunctival fever. On the other hand, type 3 virus has been isolated from cases of febrile catarrh in military recruits (Berge et al., 1955) as well as from pharyngo-conjunctival fever. In the school outbreaks of pharyngo-conjunctival fever described here type 3 virus was found in three schools, type 7 in one school, and type 14 in another school. We have not encountered type 3 virus in association with any other clinical syndrome, but type 7 was isolated from cases of febrile catarrh in extensive outbreaks in R.A.F. recruits and from sporadic civilian and military cases. The Lancing virus appeared similar to type 14 strains found by Dr. van der Veen in cases of respiratory illness in Dutch recruits and by us in a patient with febrile catarrh in an R.A.F. unit. Virus type does not therefore seem to be the only factor in determining the clinical syndrome. Trauma to the conjunctiva, either chemical or mechanical, and route of infection may be other important factors (Bell et al., 1956).

\section{Summary}

Clinical, laboratory, and epidemiological features are described of outbreaks of pharyngo-conjunctival fever associated with adenovirus infection in seven residential schools for boys.

The illnesses were characterized by three to five days' fever, sore throat, blocked nose, enlarged cervical glands, and painless conjunctivitis. A detailed clinical description based on the study of patients in two of the outbreaks is given.

Serological evidence of adenovirus infection was obtained in all seven outbreaks, and virus strains were isolated from throat washings or eye swabs from patients in five schools where this was attempted. Three of the outbreaks appeared to be due to type 3 virus, one to type 7 , and one to type 14 .

In three schools where the influence of age on susceptibility was studied, illness attack rates fell with rising age.

We are indebted to $\mathrm{Mr}$. A. J. Cameron, consulting ophthalmic surgeon to Epsom College, for slit-lamp examinations; to Dr. D. M. Stone and Dr. N. E. G. Richardson for haematological and bacteriological work; to Dr. R. A. Cocks for help in collecting blood specimens; and to the school matrons-especially Miss N. M. J. Morris, S.R.N., of Epsom College, and Miss B. Clarke, S.R.N., of Lancing College-for considerable help and forbearance during our investigations. We are grateful to Professor J. van der Veen, of the University of Nijmegen, for kindly supplying the type 14 adenovirus strain (deWit) and a quantity of homologous antiserum. Finally, we thank Drs. J. A. Boycott, L. Hoyle, K. E. Hughes, A. C. Jones, and R. L. Vollum, of the Public Health Laboratory Service, for telling us of outbreaks and for allowing us to assist in the investigations.

\section{REFERENCES}

Barker, M. H., Capps, R. B., and Allen, F. W. (1945), J. Amer. mea Ass.. 128, 997 .

Ass., 128, 997. W $\mathrm{P}$ Engler, J. I. Parrott $\mathrm{R}, \mathrm{H}$ and Huebner, (1955). Ibid., 157, 1083 .

Ward, T. G Huebner, R J., Rowe, W. P Suskind, R. G. and Paffentarger, $\ddot{\mathrm{R}}$, S. (1956). Amer. J publ. Hith, 46, 1130. (i955) O., England. B.. Mauris.

Cockburn. Amer. J. Hyg, 62. 283. Ophthal. 36, 1534

Cockburn. T. A. (1953). Amer. J. Ophthal.̈ 36, 1534. J. Hyg. 63, 250.

Derrick. E. H. (1943). Med. J. Aust.. 2. 334.

Forssell. P. Lapinleimu. K.. Strandström, H., and Oker-Blom, N (1956). Ann. Med. exp. Biol. Fenn.. 34. 287.

Ginsberg. H. S.. Gold, E., Jordan, W. S., Katz. S., Badger, G. F., and Dingle, J. H. (1955). Amer. J. publ. Hlth, 45, 915.

Guthrie, C. C., and Pessel, J. F. (1925). Amer. J. Dis. Child., 29, 492. Ormsby, H. L., and Aitchison. W. S. (1955). Canad. med. Ass. J., 73, 864 Parrott. R. H., Rowe, W. P., Huebner, R. J.. Bernton. H. W., and McCullough. N. B. (1954). New Engl. J. Med., 251. 1087.

Randolph. T. G.. and Gibson, E. B. (1944). Amer. J. med. Sci., 207, 638. Sobel, G., Aronson, B., Aronson, S., and Walker, D. (1956). J. Dis. Child., 92. 596.

Tyrrell. D. A J.. Balducci. D . and Zaiman, T. E. (1956). Lancet. 2. 1326 World Health Organization (1953). Techn. Rep. Ser.. No. 64. Geneva. 